\title{
SURVEY OF PLANTS OF NEWASA TAHASIL OF AHMEDNAGAR DISTRICT (MS, INDIA)
}

\author{
1S.R. Kale*, ${ }^{2}$ B.N. Sonawane and ${ }^{3}$ C.S. Arsule \\ 1,2Shri. Dnyaneshwar Mahavidyalaya, Newasa. Dist Ahmednagar, (M.S.) 414603. \\ ${ }^{3}$ New Arts Commerce and Science College, Ahmednagar. (M.S.). \\ *Corresponding Author: sureshkale00@gmail.com
}

\begin{abstract}
:
The Newasa area is located in the Ahmednagar district of Maharashtra. The choice of the study area the topics under investigation are influenced by many consideration. Newasa taluka located $19^{\circ}$ to $19^{\circ} 39^{1} \mathrm{~N}$ latitude and $74048^{1}$ to $75^{\circ}$ east longitude. The area is rich in vegetation shows more biodiversity of plant species. The present paper provides information regarding 32 plants belonging to 19 families survey from Newasa tahasil of Ahmednagar district (MS). Brief information about the botanical names, family, English names and local names have been presented.
\end{abstract}

Key words: biodiversity, botanical names, Newasa taluka.

\section{INTRODUCTION:}

The Newasa area is located in the Ahmednagar district of Maharashtra. The choice of the study area the topic under investigation is influenced by many consideration. Newasa taluka located $19^{0}$ to $19^{0} 39^{1} \mathrm{~N}$ latitude and $74048^{1}$ to $75^{0}$ east longitude. Floristic diversity can be defined as the variety and variability of plants in a given region. It refers to the number of types or taxa in a given region or group. Floristic diversity can be measured at any level from overall global diversity to ecosystem, community, species, populations, individuals and even to genes within a single individual. The present paper provides information regarding about the botanical names, family, English names and local names survey from Newasa tahsil of Ahmednagar district (MS).

\section{MATERIALS AND METHODS:}

1) The present study was carried out in Newasa tahasil of Ahmednagar District (MS) during 2018-2019.
2) The information regarding local name, uses and significance of plants were collected through consulting the local people through interviews, discussions and observations.

3) Several specimens of plants were collected. Most of the plants were collected fresh, photographs of collected plant species were also made, so as to enhance their identification.

4) The plant species obtained from the survey were identified using keys and description given in The Flora of Presidency of Bombay (Cooke, 1958), Flora of Marathwada (Vol. I and Vol. II) by V.N. Naik (1998) etc.

\section{RESULTS AND DISCUSSION:}

The present paper provides information regarding 32 plants belonging to 19 families survey from Newasa tahasil of Ahmednagar district (MS). Brief information about the botanical names, family, English names and local names have been presented in table no. 1. 


\section{REFERENCES:}

Cooke T. 1958. Flora of Presidency of Bombay (Reproduce edition), (Botanical Survey of India, Calcutta, India) I, II, III.

Cooke T. 1967. Flora of Presidency of Bombay

Vol. 1-3. Botanical Survey of India, Calcutta, India.

Naik V.N. 1998. Flora of Marathwada, Vol. I (Amrut Prakashan, Aurangabad).

Shirke D.R. 1983. The study of the Flora of Ahmednagar. Journal of University of
Poona, Science \& Technology,56: 55-70.

Shrestha U.B., Shrestha, B.B., Shrestha, S. 2010. Biodiversity conservation in community forests of Nepal, Internat. Journal of Biodiversity and Conservation,2 (5): 98-104.

Singh N. P. and Kartikeyan S.2000. Flora of Maharashtra State (Dicotyledones), Vol.1. Botanical Survey of India

Table No. 1.

\begin{tabular}{|c|c|c|c|c|}
\hline Sr. No. & Botnical Name & Family & English Name & Local Name \\
\hline 1. & Aegle marmelos, Corr. & Rutaceae & Bilw & Bel \\
\hline 2. & Albizia lebbeck, Benth. & Leguminosae & Shirish & Shirish \\
\hline 3. & Annona squamosa, L. & Annonaceae & Sitafalam & Sitafal \\
\hline 4. & Azadiracta indica, A. Juss & Meliaceae & Nimb & Kadunimb \\
\hline 5. & Bambusa arundinacea, Willd. & Gramineae & Vansh & Bamboo \\
\hline 6. & Bauhinia Purpurea L. & Caesalpiniaceae & Kancanara & Apata \\
\hline 7. & Butea monosperma, Taub, & Leguminosae & Palash & Palas \\
\hline 8. & Caesalpinia cristata, L. & Leguminosae & Latakaranj & Sagrkota \\
\hline 9. & Caesalpinia pulcherrima, L. & Caesalpiniaceae & Peacock flower & Shankasur \\
\hline 10. & Calotropis procera, R. BR. & Asclepiadaceae & Ark & Rui \\
\hline 11. & Cassia fistula, L. & Caesalpiniaceae & Argwada & Bahava \\
\hline 12. & Citrus aurantifolia, Swingle & Rutaceae & Nimbuk & Limbu \\
\hline 13. & Cocos nucifera, L. & Palmae & Narikel & Naral \\
\hline 14. & Dalbergia Sissoo, Roxb. & Leguminosae & Shinshpa & Shisam \\
\hline 15. & Emblica officinalis, Gaertm. & Euphorbiaceae & Amlaki & Avala \\
\hline 16. & Eucalyptus globulus, Labill. & Myrtaceae & Tailparni & Nilgiri \\
\hline 17. & Eujenia jambolana, Lam. & Myrtaceae & Jambu & Jambhul \\
\hline 18. & Ficus glamerata, Roxb. & Moraceae & Udumbar & Umbar \\
\hline 19. & Ficus religiosa, L. & Moraceae & Ashwatth & Pimpal \\
\hline 20. & Mangifera indica & Anacardiaceae & mango & Amba \\
\hline 21. & Moringa oleifera, Lamk. & Moringaceae & Shigru & Shevaga \\
\hline 22. & Polyalthia longifolia, B \& H & Annonaceae & Kashthadaru & Ashok \\
\hline 23. & Pongamia pinnata, Lour. & Leguminosae & Karanj & Karanj \\
\hline 24. & Punica granatum, L. & Punicaceae & Dadim & Dalimb \\
\hline 25. & Ricinus communis, L. & Euphorbiaceae & Erand & Erand \\
\hline 26. & Santalum album, L. & Santalaceae & Chandan & Chandan \\
\hline 27. & Sapindus trifolius, L. & Sapindaceae & Arishta & Ritha \\
\hline 28. & Sesbania grandiflora, Poir. & Papilionaceae & Agastya & Hadaga \\
\hline 29. & Tamarindus indica, $\mathrm{L}$. & Caesalpiniaceae & Amlica & Chinch \\
\hline 30. & Terminalia belerica, Roxb. & Combrataceae & Vibhitak & Behada \\
\hline 31. & Terminalia chebula, Retz. & Combrataceae & Haritaki & Hirda \\
\hline 32. & Zizyphus jujuba, Lamk. & Rhamnaceae & Unnav & Bor \\
\hline
\end{tabular}

